\title{
FAKTOR- FAKTOR YANG BERHUBUNGAN DENGAN KEJADIAN PREEKLAMPSI BERAT (PEB)
}

\author{
Silpia Novrianti, Rachmawati, Yuniarti \\ Politeknik Kesehatan Kementerian Kesehatan Bengkulu, Jurusan Kebidanan \\ silpianovrianti@yahoo.co.id
}

\begin{abstract}
Severe preeclampsia (PEB) is still one of the causes of maternal morbidity and mortality if not adequately treated. There are many things that affect the occurrence of $\mathrm{PEB}$, some of which are maternal age, parity, gestational age and education. The high incidence of PEB in the 2016. Yunus Bengkulu District Hospital Obstetric Room in 2016. The purpose of this study was to determine the factors that influence the incidence of PEB in Yunus Bengkulu Public Hospital in 2016. The design of this study was using case control, with a maternal population 1070 people in 2016 with a sample of 162 people. The analysis was carried out univariately and bivariately using Chi-Square test while multivariate analysis used Logistic Regression test. The results showed that there was a relationship between age, parity, gestational age and education with the incidence of PEB. The results of multivariate analysis showed that education had the most influential relationship to the incidence of severe preeclampsia.
\end{abstract}

Keywords:Age, Parity, Gestational age, Education, Preeclampsi Weight

\begin{abstract}
Abstrak :Preeklampsi Berat (PEB) masih merupakan salah satu penyebab morbiditas dan mortalitas ibu apabila tidak ditangani dengan adekuat. Ada banyak hal yang mempengaruhi terjadinya PEB, beberapa diantaranya adalah usia ibu, paritas, usia kehamilan dan pendidikan. Masih tingginya angka kejadian PEB di Ruang Kebidanan RSUD M.Yunus Bengkulu tahun 2016.Tujuan penelitian ini adalah untuk mengetahui faktor-faktor yang mempengaruhi kejadian PEB di RSUD.M.Yunus Bengkulu tahun 2016. Desain penelitian ini menggunakan case control, dengan populasi ibu bersalin 1070 orang pada tahun 2016 dengan jumlah sampel 162 orang. Analisis yang dilakukan secara univariat dan bivariat menggunakan uji Chi-Square sedangkan analisis multivariat menggunakan uji Regresi Logistik. Hasil penelitian menunjukkan ada hubungan usia, paritas, usia kehamilan dan pendidikan dengan kejadian PEB, Hasil analisis multivariat didapatkan bahwa pendidikan mempunyai hubungan yang paling berpengaruh terhadap kejadian Preeklampsi Berat.
\end{abstract}

Kata kunci: Usia, Paritas, Usia Kehamilan, Pendidikan dan PEB

Preeklampsi merupakan kumpulan gejala yang timbul pada ibu hamil, bersalin dan dalam masa nifas yang terdiri dari trias : hipertensi, proteinuri, dan edema, yang kadang-kadang di sertai konvulsi sampai koma. Preeklampsi merupakan salah satu penyebab utama morbiditas dan mortalitas perinatal di Indonesia, sampai sekarang penyakit preeklampsi masih merupakan masalah kebidanan yang belum dapat terpecahkan secara tuntas.Preeklampsi merupakan penyakit yang angka kejadiannya di setiap negara berbeda-beda. Sampai saat ini terjadinya preeklampsi belum di ketahui penyebabnya, tetapi preeklampsi berat dapat terjadi pada kelompok tertentu yaitu mereka yang mempunyai predisposing usia muda, kehamilan pertama, keturunan dan riwayat preeklampsi (Wiknjosastro, 2010).

Menurut laporan World Health Organization (WHO) tahun 2014 Angka Kematian ibu (AKI) di dunia yaitu 289.000 jiwa. Beberapa negara memiliki AKI cukup tinggi seperti Afrika SubSaharan 179.000 jiwa, Asia Selatan 69.000 jiwa, dan Asia Tenggara 16.000 jiwa. Angka kematian ibu di negara-negara Asia Tenggara yaitu Indonesia 190 per 100.000 kelahiran hidup, Vietnam 49 per 100.000 
kelahiran hidup, Thailand 26 per 100.000 kelahiran hidup, Brunei 27 per 100.000 kelahiran hidup, dan Malaysia 29 per 100.000 kelahiran hidup (WHO, 2014).Penyebab kematian ibu di Indonesia masih di dominasi oleh perdarahan $(32 \%)$ dan hipertensi dalam kehamilan $(25 \%)$ diikuti oleh infeksi (5\%) partus lama (5\%) dan abortus (1\%). Selain penyebab obstetrik, kematian ibu juga disebabkan oleh penyebab lain-lain (non obstetrik) sebesar (32\%) (Kemenkes RI, 2012).

Menurut penelitian Iyam Manueke, dkk. 2013. Didapatkan hasil bahwa ada hubungan yang signifikan antara umur ibu dengan kejadian preeklampsia di ruang ruang bersalin RSUP. Prof. Dr. R.D. Kandou Manado tahun 2013. Sedangkan hasil penelitian Ria Maryanti, 2012. Didapatkan hasil ada hubungan yang bermakna antara pendidikan ibu dengan kejadian preeklampsi berat di PT. Graha Pusri Medika/ Rumah Sakit Pusri Palembang Tahun 2014.

Di Provinsi Bengkulu, angka kematian ibu masih cukup tinggi. Berdasarkan data profil kesehatan kabupaten/kota di Provinsi Bengkulu pada tahun 2015, secara absolut jumlah kematian ibu yakni sebanyak 15 orang, yang terdiri dari kematian ibu hamil sebanyak 2 orang, kematian ibu bersalin sebanyak 1 orang dan kematian ibu nifas sebanyak 12 orang, maka dengan demikian angka kematian ibu di Provinsi Bengkulu pada tahun 2015 yaitu sebesar 224 per $100.000 \mathrm{KH}$ meningkat sedikit dari tahun 2014 yang sebesar 146 per $100.000 \mathrm{KH}$.

Rumah sakit RSUD Dr.M.Yunus merupakan rumah sakit yang menampung pelayanan rujukan dari rumah sakit kabupaten. Berdasarkan data yang diperoleh dari RSUD Dr.M.Yunus Bengkulu menyebutkan bahwa pada tahun 2014 kasus preeklamsi berat sebanyak 121 $(5,52 \%)$ kasus dari 2.191 ibu bersalin. Pada tahun 2015 data ibu preeklampsi berat sebanyak $101(8,31 \%)$ kasus dari 1.215 ibu yang besalin. Survei awal yang diperoleh dari ruang Mawar RSUD
Dr.M.Yunus Bengkulu pada tanggal 9 maret 2017 terdapat $1.070 \mathrm{ibu}$ hamil yang bersalin dengan 99(9,25\%) kasus Preeklampsi Berat di tahun 2016.

Tujuan Penelitian untuk melakukan penelitian mengenai Faktor-Faktor yang Berhubungan dengan Kejadian Preeklampsi Berat Di RSUD Dr.M.Yunus Bengkulu Tahun 2016.

\section{BAHAN DAN CARA KERJA}

Desain penelitian ini menggunakan survey analitik dengan rancangan case control retrospektif. Dalam penelitian ini dilakukan pengukuran variabel dependen (kejadian pre eklampsi berat) diidentifikasi pada saat ini, kemudian variabel independen (usia, paritas, usia kehamilan dan pendidikan,) diidentifikasi adanya atau terjadinya pada waktu yang lalu (Notoatmodjo, 2010).Populasi dalam penelitian ini adalah ibu-ibu yang bersalin tahun 2016 di Rumah Sakit Dr.M.Yunus Bengkulu sebanyak 1070 orang.Data sampel yang diambil 162 perbandingan kelompok kasus dan kontrol adalah 1:1, yaitu 81 untuk kasus dan 81 untuk control.

\section{HASIL}

\section{Analisis Univariat}

Tabel 1 Distribusi Frekuensi Responden Berdasarkan Usia, Paritas, Usia Kehamilan, Pendidikan Dan PEB di Ruang Kebidanan RSUD M.Yunus Bengkulu Tahun 2016

\begin{tabular}{llcc}
\hline No & Variabel & F & \% \\
\hline $\mathbf{1}$ & Usia & & \\
& <20 Tahun & 9 & 5,6 \\
& 20-35 Tahun & 91 & 56,2 \\
& $>35$ Tahun & 62 & 38,8 \\
& Jumlah & $\mathbf{1 6 2}$ & $\mathbf{1 0 0}$ \\
$\mathbf{2}$ & Paritas & & \\
& Primigravida & 34 & 21,0 \\
& Multigravida & 104 & 64,2 \\
& Grande Multigravida & 24 & 14,8 \\
& Jumlah & $\mathbf{1 6 2}$ & $\mathbf{1 0 0}$ \\
$\mathbf{3}$ & Usia Kehamilan & & \\
& Preterm & & \\
& Aterm & 78 & 48,1 \\
& Post Term & 80 & 49,4 \\
& & 4 & 2,5 \\
& Jumlah & $\mathbf{1 6 2}$ & $\mathbf{1 0 0}$ \\
\hline
\end{tabular}




\begin{tabular}{|c|c|c|c|}
\hline \multirow[t]{4}{*}{4} & \multicolumn{3}{|l|}{ Pendidikan } \\
\hline & Pendidikan Dasar & 84 & 51,9 \\
\hline & Pendidikan Menengah & & \\
\hline & Pendidikan Tinggi & 46 & 28,4 \\
\hline & & 32 & 19,8 \\
\hline & Jumlah & 162 & 100 \\
\hline
\end{tabular}

Berdasarkan tabel 1 menjelaskan bahwa dari 162 responden, didapatkan hasil sebagian $(56,6 \%)$ adalah ibu dengan usia 20-35 tahun, sebagian $(64,2 \%)$ adalah ibu dengan paritas multigravida, hampir sebagian $(49,4 \%)$ dengan usia kehamilan aterm serta sebagian $(51,9 \%)$ ibu pendidikan dasar.

\section{Analisis Bivariat}

Tabel 2 Hubungan Usia Dengan Kejadian PEB di Ruang Kebidanan RSUD M.Yunus Bengkulu Tahun 2016

\begin{tabular}{|c|c|c|c|c|c|c|}
\hline \multirow{3}{*}{ Usia } & \multicolumn{4}{|c|}{ Kejadian PEB } & \multirow{3}{*}{$\begin{array}{c}\text { Nilai } \\
\rho\end{array}$} & \multirow{3}{*}{ OR } \\
\hline & \multicolumn{2}{|c|}{ PEB } & \multicolumn{2}{|c|}{ Tidak PEB } & & \\
\hline & $\mathrm{N}$ & $\%$ & $\mathrm{~N}$ & $\%$ & & \\
\hline $\begin{array}{l}\text { Berisiko } \\
(<20\end{array}$ & 45 & 55,6 & 29 & 35,8 & & \\
\hline dan $>35$ & & & & & 0,01 & 2,24 \\
\hline Tahun) & & & & & 8 & 1 \\
\hline Tidak & 36 & 44,4 & 52 & 64,2 & & \\
\hline Berisiko & & & & & & \\
\hline$(20-35$ & & & & & & \\
\hline Tahun) & & & & & & \\
\hline Jumlah & 81 & 100 & 81 & 100 & & \\
\hline
\end{tabular}

Berdasarkan hasil analisis tabel 2 menunjukkan bahwa dari 81 kasus preekalmpsi berat sebagian $45(55,6 \%) \mathrm{ibu}$ berusia $<20$ tahun dan $>35$ tahun sedangkan dari 81 ibu yang tidak mengalami preeklampsi berat hampir sebagian $29(35,8 \%)$ berusia $<20$ tahun dan $>35$ tahun. Hasil uji statistik diperoleh nilai $p=0,018<0,05$ artinya ada hubungan yang bermakna antara usia dengan kejadian preeklampsi berat, dengan nilai $\mathrm{OR}=2,241$ bearti ibu yang mengalami preeklampsi berat memiliki risiko 2,241 kali pada usia $<20$ dan $>35$ tahun dibandingkan dengan ibu dengan usia 2035 tahun.

Tabel 3 Hubungan Paritas Dengan Kejadian PEB di Ruang Kebidanan RSUD M.Yunus Bengkulu Tahun 2016

\begin{tabular}{|c|c|c|c|c|}
\hline \multirow{3}{*}{ Paritas } & \multicolumn{2}{|c|}{ Kejadian PEB } & \multirow{3}{*}{$\begin{array}{l}\text { Nila } \\
\text { i } \rho\end{array}$} & \multirow{3}{*}{ OR } \\
\hline & PEB & Tidak PEB & & \\
\hline & $\mathrm{N}$ & $\mathrm{N}$ & & \\
\hline
\end{tabular}

\begin{tabular}{lcccccc}
\hline $\begin{array}{l}\text { Multigra } \\
\text { vida }\end{array}$ & 76 & 93,8 & 53 & 65,4 & 0,00 & 0,1 \\
$\begin{array}{l}\text { Primigra } \\
\text { vida }\end{array}$ & 5 & 6,2 & 28 & 34,6 & 0 & 25 \\
\begin{tabular}{l} 
Jumlah \\
\hline
\end{tabular} & 81 & 100 & 81 & 100 & & \\
\hline
\end{tabular}

Hasil analisis tabel 3 menunjukkan bahwa dari 81 kasus preeklampsi berat hampir seluruh $76(93,8 \%)$ ibu dengan paritas multigravida, sedangkan dari $81 \mathrm{ibu}$ yang tidak mengalami preeklampsi berat sebagian $53(65,4 \%)$ ibu dengan paritas multigravida. Hasil uji statistik diperoleh nilai $\mathrm{p}=0,000<0,05$ artinya ada hubungan yang bermakna antara paritas dengan kejadian preeklampsi berat, dengan nilai $\mathrm{OR}=0,125$ menunjukkan bahwa ibu yang mengalami preeklampsi berat memiliki resiko 0,125 kali pada multigravida dibandingkan ibu dengan primigravida.

Tabel 4 Hubungan Usia Kehamilan Dengan Kejadian PEB Di Ruang Kebidanan RSUD M.Yunus Bengkulu Tahun 2016

\begin{tabular}{|c|c|c|c|c|c|c|}
\hline \multirow{3}{*}{$\begin{array}{c}\text { Usia } \\
\text { Kehamil } \\
\text { an }\end{array}$} & \multicolumn{4}{|c|}{ Kejadian PEB } & \multirow{3}{*}{$\begin{array}{c}\text { Nilai } \\
\rho\end{array}$} & \multirow{3}{*}{$\begin{array}{l}\mathrm{O} \\
\mathrm{R}\end{array}$} \\
\hline & \multicolumn{2}{|c|}{ PEB } & \multicolumn{2}{|c|}{ Tidak PEB } & & \\
\hline & $\mathrm{N}$ & $\%$ & $\mathrm{~N}$ & $\%$ & & \\
\hline Preterm & 46 & $\begin{array}{c}56, \\
8\end{array}$ & 32 & 39,5 & 0,041 & 2,0 \\
\hline Aterm & 35 & $\begin{array}{c}43, \\
2\end{array}$ & 49 & 60,5 & & 12 \\
\hline Jumlah & 81 & $\begin{array}{c}10 \\
0\end{array}$ & 81 & 100 & & \\
\hline
\end{tabular}

Berdasarkan hasil analisis tabel 4 menunjukkan bahwa dari 81 kasus preekalmpsi berat sebagian $46(56,8 \%)$ ibu dengan usia kehamilan preterm, sedangkan dari 81 ibu yang tidak mengalami preeklampsi berat hampir sebagian 32 $(39,5 \%)$ usia kehamilan preterm. Hasil uji statistik diperoleh nilai $p=0,041<0,05$ artinya ada hubungan yang bermakna antara usia kehamilan dengan kejadian preeklampsi berat, dengan nilai $\mathrm{OR}=$ 2,012 bearti ibu yang mengalami preeklampsi berat memiliki risiko 2,012 kali pada usia kehamilan preterm dibandingkan dengan usia kehamilan aterm.

Tabel 5 Hubungan Pendidikan Dengan Kejadian PEB Di Ruang Kebidanan RSUD M.Yunus Bengkulu Tahun 2016 


\begin{tabular}{|c|c|c|c|c|c|c|}
\hline \multirow{3}{*}{ Pendidikan } & \multicolumn{4}{|c|}{ Kejadian PEB } & \multirow{3}{*}{$\begin{array}{c}\text { Nil } \\
\text { ai } \\
\rho\end{array}$} & \multirow{3}{*}{ OR } \\
\hline & \multicolumn{2}{|c|}{ PEB } & \multicolumn{2}{|c|}{ Tidak PEB } & & \\
\hline & $\mathrm{N}$ & $\%$ & $\mathrm{~N}$ & $\%$ & & \\
\hline $\begin{array}{l}\text { Pendidikan } \\
\text { Dasar }\end{array}$ & 52 & $\begin{array}{c}64, \\
2\end{array}$ & 32 & 39,5 & & \\
\hline Pendidikan & 29 & 35 , & 49 & 60,5 & 0,0 & 2,74 \\
\hline $\begin{array}{l}\text { Menengah } \\
\text { dan PT }\end{array}$ & & 8 & & & 03 & 6 \\
\hline Jumlah & 81 & $\begin{array}{c}10 \\
0\end{array}$ & 81 & 100 & & \\
\hline
\end{tabular}

Berdasarkan hasil analisis tabel 5 menunjukkan bahwa dari 81 kasus preekalmpsi berat sebagian $52(64,2 \%) \mathrm{ibu}$ dengan pendidikan dasar, sedangkan dari 81 ibu yang tidak mengalami preeklampsi berat hampir sebagian $32 \quad(39,5 \%)$ pendidikan dasar. Hasil uji statistik diperoleh nilai $p=0,003<0,05$ artinya ada hubungan yang bermakna antara pendidikan dengan kejadian preeklampsi berat, dengan nilai $\mathrm{OR}=2,746$ bearti ibu yang mengalami preeklampsi berat memiliki risiko 2,746 kali pada pendidikan dasar dibandingkan dengan pendidikan menengah dan pendidikan tinggi.

\section{Analisis Multivariat}

\begin{tabular}{|c|c|c|c|c|}
\hline \multirow[t]{2}{*}{ Variabel } & \multirow[t]{2}{*}{$\begin{array}{c}P \\
\text { Value }\end{array}$} & \multirow[t]{2}{*}{$\begin{array}{l}\text { Exp } \\
\text { (B) }\end{array}$} & \multicolumn{2}{|c|}{$\begin{array}{l}\text { 95\% C.I.for } \\
\text { EXP(B) }\end{array}$} \\
\hline & & & $\begin{array}{c}\text { Lowe } \\
\mathrm{r}\end{array}$ & Upper \\
\hline Usia & 0,124 & 1,715 & 0,863 & 3,411 \\
\hline Paritas & 0,001 & 0,168 & 0,059 & 0,475 \\
\hline Usia & 0,113 & 1,738 & 0,877 & 3,444 \\
\hline kehamilan & 0,029 & 2,145 & 1,080 & 4,260 \\
\hline
\end{tabular}

Berdasarkan hasil analisis tabel 7 diatas beberapa variabel memiliki nilai $\mathrm{p}<$ 0,05 kecuali variabel usia dengan nilai $p$ 0,124 dan usia kehamilan nilai p 0,113 sehingga pemodelan selanjutnya variabel usia dan usia kehamilan dikeluarkan dari model, dengan langkah yang sama dilakukan kembali analisis regresi tapi variabel usia dan usia kehamilan tidak diikutsertakan (dikeluarkan dari model) diperoleh hasil sebagai berikut.

Tabel 7 Regresi Logistik Berganda Faktor Yang Berhubungan Dengan Kejadian Preeklampsi
Berat (PEB) Di RSUD M.Yunus Bengkulu Tahun 2016

\begin{tabular}{lcccc}
\hline Variabel & $P$ & Exp (B) & \multicolumn{2}{c}{$\begin{array}{c}\text { 95\% C.I.for } \\
\text { VXP(B) }\end{array}$} \\
\cline { 4 - 5 } & & & Lower & Upper \\
\hline Paritas & 0,000 & 0,146 & 0,052 & 0,407 \\
$\begin{array}{l}\text { Pendidik } \\
\text { an }\end{array}$ & 0,019 & 2,234 & 1,139 & 4,380 \\
\hline
\end{tabular}

Berdasarkan hasil analisis tabel 8 tersebut menunjukkan bahwa kedua variabel independen memiliki nilai $\mathrm{p}<$ 0,05 . Hal tersebut bearti variabel paritas dan pendidikan memiliki hubungan yang bermakna secara statistik. Variabel yang paling berpengaruh dalam penelitian ini adalah pendidikan hal tersebut dibuktikan dengan hasil analisis didapatkan nilai Odds Ratio (OR) yang paling besar diimiliki variabel pendidikan yaitu 2,234.

\section{PEMBAHASAN}

\section{Hubungan Usia Dengan Kejadian PEB}

Hasil analisis menjelaskan bahwa kejadian preeklampsi berat sebagian 45 $(55,6 \%)$ yang terjadi pada ibu usia $<20$ tahun dan $>35$ tahun, sedangkan yang tidak mengalami preeklampsi berat hampir sebagian $29(35,8 \%)$ berusia $<20$ tahun dan $>35$ tahun. Hasil uji statistik diperoleh nilai $\mathrm{p}=0,018$ artinya ada hubungan yang bermakna antara usia dengan kejadian preeklampsi berat, dengan hasil OR = 2,241 bearti ibu yang mengalami preeklampsi berat memiliki risiko 2,241 kali pada usia $<20$ dan $>35$ tahun dibandingkan dengan ibu dengan usia 2035 tahun.

Hasil penelitian ini sejalan dengan penelitian-penelitian sebelumnya, menurut hasil penelitian Ria Maryanti (2013), menunjukkan dari 103 responden dilihat bahwa usia ibu yang resiko tinggi sebanyak reponden $(14,6 \%)$, sedangkan ibu dengan usia resiko rendah yaitu sebanyak 28 reponden $(5,8 \%)$, hal ini menunjukkan ada hubungan yang bermakna antara usia ibu dengan kejadian preeklampsi berat, dari hasil penelitian ini ialah bertambahnya umur merupakan salah satu faktor resiko yang mengakibatkan 
preeklampsi berat, karena semakin bertambahnya umur seseorang, maka lebih mudah terserang penyakit dan terjadinya perubahan pada alat kandungan, sehingga pada usia 35 tahun atau lebih dapat cendrung meningkatkan resiko terjadinya preeklampsi beratt.

Hasil tersebut juga dipertegas oleh hasil penelitian yang sudah pernah dilakukan oleh Devi Kurniasari (2015) menunjukkan bahwa hasil analisis antara usia ibu dengan kejadian preeklampsi diperoleh dari 43 ibu dengan usia berisiko (usia $<20$ tahun dan $>35$ tahun) yang mengalami preeklampsi berat yaitu (74,4\%), sedangkan ibu dengan usianya tidak berisiko yang mengalami preeklampsi berat $(15,8 \%)$. Hasil uji statistik didapatkan bahwa ada hubungan yang signifikan antara usia ibu dengan kejadian preeklampsi, dengan nilai $\mathrm{OR}=$ 15,51 artinya ibu usia $<20$ tahun dan $>35$ tahun memiliki peluang 15,51 kali mengalami preeklampsi dibandingkan dengan ibu yang memiliki usia 20-35 tahun.

Hasil penelitian ini sesuai dengan teori Cuningham (2009) Menifestasi utama dari proses ini adalah menurunnya kemampuan fungsi organ dan sistem tubuh, diantaranya yaitu otot, syaraf, kardiovaskuler, endokrin dan reproduksi. Tetapi pada umumnya tanda-tanda penuaan mulai tampak sejak umur lebih 35 tahun telah terjadi penurunan curah jantung yang disebabkan oleh berkurangnya kontraksi miokardium, sedangkan pada saat hamil curah jantung meningkat (40\%) untuk meningkatkan aliran darah ke organ seperti ginjal dan uterus. Sehingga terjadi peningkatan curah jantung dapat meningkatkan tahanan perifer yang berakibat daya pompa jantung meningkat sehingga terjadi kontraksi yang menyebabkan tekanan darah menjadi tinggi .

Usia reproduktif dari seorang wanita adalah 20-35 tahun., usia reproduktif ini merupakan periode yang paling aman untuk hamil dan melahirkan karena pada usia tersebut resiko terjadinya komplikasi selama kehamilan lebih rendah. Usia dibawah 20 tahun dan di atas 35 tahun disebut juga sebagai usia resiko tinggi untuk mengalami komplikasi selama kehamilan, pada usia $<20$ tahun ukuran uterus belum mencapai ukuran yang normal untuk kehamilanm, sehingga kemungkinan terjadinya gangguan dalam kehamilan seperti preeklampsi menjadi lebih besar, pada usia >35 tahun terjadi proses degeratif yang mengakibatkan perubahan structural dan fungsional yang terjadi pada pembuluh darah perifer yang bertanggung jawab terhadap perubahan tekanan darah, sehingga lebih rentan mengalami preeklampsi (Sudarti, 2013).

\section{Hubungan Paritas Dengan Kejadian PEB}

Hasil analisis menjelaskan bahwa kejadian preeklampsi berat hampir seluruh $76 \quad(93,8 \%)$ ibu dengan paritas multigravida, sedangkan ibu yang tidak mengalami preeklampsi berat sebagian 53 $(65,4 \%)$ ibu dengan paritas multigravida. Hasil uji statistik diperoleh nilai $\mathrm{p}=0,000$ artinya ada hubungan yang bermakna antara paritas dengan kejadian preeklampsi berat, dengan nilai $\mathrm{OR}=0,125$ menunjukkan bahwa ibu yang mengalami preeklampsi berat memiliki resiko 0,125 kali pada multigravida dibandingkan ibu dengan primigravida.

Penelitian ini sejalan dengan penelitian Devi Kurniasari (2015) menunjukkan bahwa responden dengan paritas primipara sebanyak 22 responden, sebagian besar mengalami preeklampsi sebanyak 12 (54\%) responden, sedangkan responden yang tidak mengalami kejadian preeklampsi $10 \quad(45,5 \%)$ respoden. Responden dengan paritas multipara sebanyak 46 responden, sebanyak 43 $(93,5 \%)$ responden mengalami kejadian preeklampsi lebih besar dibandingkan yang tidak mengalami preeklampsi sebanyak $3(6,5 \%)$ responden, responden dengan paritas grande multipara sebanyak 1 responden, secara keseluruhan sebanyak $(100 \%)$ responden tidak mengalami 
kejadian preeklampsi. Hasil uji statistik menunjukkan bahwa ada hubungan paritas dengan kejadian preeklampsi berat.

Penelitian ini juga di dukung oleh penelitian Sitti Nur Afridasari (2013) subyek dengan status gravida (primigravida) berjumlah 35 orang $(22,2 \%)$ yang mengalami kasus peeklampsi dan pada kelompok kontrol berjumlah 55 orang (34\%), sedangkan subyek dengan status gravid (multigravida) yang mengalami kasus preeklampsi berjumlah 44 orang $(27,8 \%)$ pada kelompok kontrol berjumlah 24 orang $(15,2 \%)$. Hasil uji statistik menunjukkan ada hubungan paritas dengan kejadian preeklampsi.

Penelitian ini sejalan dengan teori yang dikemukakan Cuningham (2009) untuk mencegah agar ibu tidak mengalami PEB perlu pencegahan preventif yaitu meningkatkan dilakukan pemeriksaan kehamilan secara berkala minimal 4 kali selama kurun kehamilan dan dimulai sejak umur kehamilan muda. Ibu hamil yang diduga berisiko, terutama faktor risiko yang mengarah akan mengalami PEB harus cepat dilaporkan, dipantau dan dirujuk pada institusi pelayanan kesehatan yang lebih mampu dan hendaknya ibu dapat merencanakan persalinannya. Bila kehamilan tersebut terjadi pada ibu multigravida maka petugas kesehatan dapat memberikan penyuluhan kesehatan tentang pertumbuhan dan perkembangan janin dalam rahim, tanda-tanda bahaya selama kehamilan dan perawatan diri selama kehamilan agar mereka dapat menjaga kesehatannya dan janin yang dikandung dengan baik dan dapat meningkatkan akses terhadap pemanfaatan pelayanan antenatal dan status gizi ibu selama hamil.

Menurut Patricia (2016) preeklampsi berat paling banyak ditemukan pada paritas multigravida hasil penelitian ini tidak sejalan dengan teori yang menyatakan bahwa preeklampsi berat sering terjadi pada kehamilan pertama (primigravida).
Hal ini tidak sejalan dengan teori yang telah dikemukanan oleh Siswosudarmo (2009), primigravida lebih berisiko untuk mengalami preeklampsi dari pada multigravida karena preeklampsi biasanya timbul pada wanita yang pertama kali terpapar vilus korion. Hal ini terjadi karena pada wanita tersebut mekanisme imunologik pembentukan blocking antibody yang dilakukan oleh HLA-G (human leukocyte antigen G) terhadap antigen plasenta belum terbentuk secara sempurna, sehingga proses implantasi trofoblas kejaringan desidual ibu menjadi terganggu. Primigravida juga rentan mengalami stress dalam menghadapi perslinan yang akan menstimulasi tubuh untuk mengeluarkan kortisol. Efek kortisol adalah meningkatkan respon simpatis, sehingga curah jantung dan tekanan darah juga akan meningkat.

\section{Hubungan Usia Kehamilan Dengan - Kejadian PEB}

Hasil analisis menjelaskan bahwa kejadian preeklampsi berat hampir sebagian $46(56,8 \%)$ yang terjadi pada usia kehamilan preterm, sedangkan yang tidak mengalami preeklampsi berat hampir sebagian $32(39,5 \%)$ usia kehamilan preterm. Hasil uji stastistik diperoleh nilai $\mathrm{p}=0,041$ artinya ada hubungan yang bermakna antar usia kehamilan dengan kejadian preeklampsi berat, dengan nilai $\mathrm{OR}=2,012$ bearti ibu yang mengalami preeklampsi berat memiliki risiko 2,012 kali pada usia kehamilan preterm dibandingkan dengan usia kehamilan aterm.

Penelitian ini tidak sejalan dengan penelitian Palesa Mayang Sulbasari (2012), yang menunjukkan bahwa pada kasus hampir seluruhnya $(76,1 \%)$ mengalami PEB pada ibu dengan usia kehamilan aterm, dan terdapat hubungan yang bermakna antara usia kehamilan dengan kejadian PEB. Hal ini dikarenakan banyak faktor salah satunya kurangya pengetahuan ibu tentang bagaiman cara merawat kehamilan. Ibu dengan kehamilan 
aterm biasanya keadaannya sudah semakin lemas dan letih salah satunya karena semakin tua kehamilan maka semakin besar janin.Sehingga untuk merawat diri agar tidak mengalami penyakit selama kehamilan jarang untuk dilakukan.

Penelitian juga tidak di dukung oleh Sulastrianah (2013) yang menunjukkan bahwa 158 sampel terlihat subyek dengan umur kehamilan pada trimester 3 berjumlah 51 orang $(32,3 \%)$ yang mengalami kehamilan dengan preeklampsi dan 30 orang $(19,0 \%)$ dengan kehamilan normal, sedangkan subyek dengan umur kehamilan pada trimester 1-2 yang mengalami preeklampsi pada kehamilannya berjumlah 28 orang $(17,7 \%)$ dan 49 orang $(31,0 \%)$ sisanya dengan kehamilan yang normal, terlihat bahwa subyek ibu hamil yang umur kehamilannya pada trimester 3 kecendrungan mengalami preeklampsi bila dibandingkan dengan subyek ibu hamil yang umur kehamilannya pada trimester 1-2. Umur kehamilan merupakan faktor resiko kejadian preeklampsi, preeklampsi dapat terjadi pada usia kehamilan di trimester 3 atau mendekati saat kelahiran, dan berefek buruk pada sistem kekebalan tubuh termasuk pada plasenta yang menyediakan zat gizi bagi janin.

Hasil penelitian ini tidak sesuai dengan teori dari Wiknjosasytro (2007) yang menyatakan pada kondisi kehamilan normal terjadi proses apoptosis yang berperan dalam pergantian sitotrofoblas dan pembaruan pembekuan sinsitium dari villi korialis, lalu dikeluarkan protein $\mathrm{BcL}-$ 2 menurun, maka proses opoptosis pada sel sinsitiotrofoblas plasenta meningkat, sehingga terjadi preeklampsi berat atau dapat dikarenakan oleh penyempitan arteri spiralis sampai 200, sedangkan pada kehamilan normal arteri spiralis yaitu 200, menyebabkan penghambatan respon yang adekuat terhadap peningkatan aliran darah, jadi perfusi plasenta menurun akan berdampak lepasnya radikal bebas dan iskemia plasenta yang merangsang peningkatan apoptosis. Semua kejadian diatas terjadi seiring dengan makin tuanya usia kehamilan. Hal ini menyebabkan preeklampsi sering terjadi pada kehamilan aterm.

Preeklampsi atau hipertensi akibat kehamilan merupakan salah satu komplikasi yang dapat terjadi selama kehamilan.Komplikasi ini dapat dijadikan alasan untuk menginduksi (merangsang) persalinan darurat agar ibu dan anak dapat diselamatkan.Preeklampsi yang terjadi selama kehamilan dapat ringan atau parah.Tekanan darah tinggi dapat mengakibatkan penurunan jumlah zat asam yang mengalir dari darah tubuh ibu ke janin melalui plasenta.Sebagai akibat penurunan zat asam ini, janin tidak berhasil berkembang dan tumbuh secara normal. Preeklampsi yang tidak dapat di tanggulangi merupakan suatu bahaya bagi sang ibu. Ia dapat terserang kejang-kejang yang membahayakan dirinya dan janin yang dikandungnya ini bearti bahwa ibu hamil mengalami preeklampsi harus segera diputuskan untuk melahirkan bayi secara prematur (Cuningham, 2009)

\section{Hubungan Pendidikan Dengan Kejadian PEB}

Hasil analisis menjelaskan bahwa kejadian preeklampsi berat sebagian 52 $(64,2 \%)$ ibu dengan pendidikan dasar, sedangkan yang tidak mengalami preeklampsi berat hampir sebagian 32 $(39,5 \%)$ pendidikan dasar. Hasil uji statistic diperoleh nilai $\mathrm{p}=0,003$ artinya ada hubungan yang bermakna antara pendidikan dengan kejadian preeklampsi berat, dengan nilai $\mathrm{OR}=2,746$ berarti ibu yang mengalami preeklampsi berat memiliki resiko 2,746 kali pada pendidikan dasar dibandingkan dengan pendidikan menengah dan pendidikian tinggi.

Penelitian ini sejalan dengan penelitian Ria Maryanti (2013) yang menunjukkan bahwa dari 584 responden, ibu dengan kategori pendidikan tinggi sebanyak 178 responden $(30,5 \%)$ dan ibu dengan pendidikan rendah sebanyak 406 
responden $(69,5 \%)$, dari 178 responden dilihat bahwa ibu dengan kategori pendidikan tinggi yang mengalami preeklampsi berat yaitu sebanyak 21 responden $(5,2 \%)$, sedangkan ibu dengan kategori pendidikan rendah sebanyak 22 responden $(12,4 \%)$. Hasil uji statistik menunjukkan ada hubungan yang bermakna antara pendidikan dengan preeklampsi berat.

Penelitian ini juga sejalan dengan hasil penelitian Agung Supriandono (2010), menyebutkan bahwa $80(49,7 \%)$ kasus preeklampsi berat mempunyai pendidikan rendah < SMA disbanding 72 $(44,2 \%)$ kasus preeklampsi berat berpendidikan tinggi > SMA. Hasil uji statistik menyimpulkan ada hubungan yang signifikan antara pendidikan dengan kejadian preeklampsi berat pada ibu bersalin.

Pendidikan ibu berpengaruh terhadap preeklampsi berat, karena ibu yang kurang berpendidikan ibu kurang mengerti akan pentingnya memeriksakan kehamilan dan apabila ada kelainan pada kehamilan maka tidak dapat terdeteksi secara dini dan apabila ibu rajin dalam memeriksakan kehamilan maka ibu akan mengetahui apakah ibu mempunyai masalah kesehatan misalnya, tekanan darah tinggi dan lain sebagainya. Maka dari itulah pentingnya seorang ibu tersebut berpendidikan tinggi (Maryanti, 2012).

Faktor yang paling dominan berhubungan dengan kejadian Preeklampsi Berat (PEB).Berdasarkan hasil analisis variabel yang paling dominan dalam penelitian ini adalah Pendidikan dengan hasil uji OR didapatkan nilai 2,234 yang artinya pendidikan 2,234 kali lebih besar mengalami kejadian Preeklampsi Berat dibandingkan dengan usia, paritas dan usia kehamilan.

Hasil penelitian Neneng Julianti (2014), menunjukkan bahwa ada hubungan yang signifikan antara pendidikan dengan kejadian preeklampsi berat, ibu yang mengalami preeklampsi berat berisiko
2,202 kali lebih besar dibandingkan dengan ibu yang berpendidikan tinggi.

Penelitian ini dipeertegas oleh penelitian Ria Maryanti (2013) yang menunjukkan bahwa ada hubungan yang bermakna antara pendidikan dengan kejadian preeklampsi, ibu yang berpendidikan rendah berisiko 2,238 untuk terjadi preeklampsi berat dibandingkan dengan ibu yang berpendidikan menangah dan pendidikan tinggi.

Hal ini didukung dengan teori Notoadmojo (2010) bahwa Tingkat pendidikan yang cukup akan lebih muda dalam mengidentifikasi stressor dalam diri sendiri maupun dari luar dirinya. Tingkat pendidikan juga mempengaruhi kesadaran dan pemahaman tentang stimulus.Tingkat pendidikan seseorang berpengaruh dalam memberikan respon terhadap sesuatu yang datang baik dari dalam maupun dari luar. Orang yang mempunyai pendidikan tinggi akan memberikan respon yang lebih rasional dibandingkan mereka yang tidak berpendidikan.

Pendidikan ibu berpengaruh terhadap preeklampsi berat, karena ibu yang kurang berpendidikan ibu kurang mengerti akan pentingnya memeriksakan kehamilan dan apabila ada kelainan pada kehamilan maka tidak dapat terdeteksi secara dini dan apabila ibu rajin dalam memeriksakan kehamilan maka ibu akan mengetahui apakah ibu mempunyai masalah kesehatan misalnya, tekanan darah tinggi dan lain sebagainya. Maka dari itulah pentingnya seorang ibu tersebut berpendidikan tinggi (Maryanti, 2012).

Berdasarkan hasil di atas bahwa usia , paritas, usia kehamilan dan pendidikan di dapatkan hasil bahwa semua ada hubungan dan faktor yang paling dominan adalah variabel pendidikan, dari hasil di atas kelamahan penelitian ini adalah tidak melakukan penelitian tentang riwayat persalinan yang lalu.

\section{KESIMPULAN}

Berdasarkan hasil penelitian dan pembahasan, tentang faktor-faktor yang 
berhubungan dengan kejadian Preeklampsi Berat (PEB) di ruang kebidanan RSUD M.Yunus Bengkulu tahun 2016, dapat ditarik kesimpulan sebagai berikut yaitu sebagian responden yang mengalami Preeklampsi Berat (PEB) adalah ibu dengan usia 20-35 tahun, ibu dengan paritas multigravida, dan ibu yang berpendidikan dasar, sedangkan hampir sebagian ibu yang mengalami Preeklampsi Berat (PEB) adalah ibu dengan usia kehamilan aterm,

\section{DAFTAR RUJUKAN}

Arikunto, S. 2011. Prosedur Penelitian Suatu Pendekatan.Jakarta : Rineka Cipta

Budiarto, E. 2007.Biostatistik Untuk Kedokteran dan Kesehatan Mayarakat. Jakarta : EGC

Cunningham. 2009. Obstetri Williams. Jakarta : Edisi 21 EGC

Dewi, Niwang A. 2016. Patologi dan Patofisologi Kebidanan. Yogyakarta : Nuha Medika

Dinas Kesehatan Kota Bengkulu.2015. Profil Kesehatan Kota Bengkulu 2015. Bengkulu

Dinas Kesehatan Propinsi Bengkulu. 2015. Profil Kesehatan Propinsi Bengkulu. Dinas Kesehatan Propinsi Bengkulu.

Iyam Manuake, dkk. 2014. Faktor-Faktor Yang Berhubungan Dengan Kejadian Preeklampsi Di RSUP Manado Provinsi Sulawesi utara. Jurnal Ilmiah Bidan vol 2 no 2.

Julianti Neneng. 2014. Faktor-faktor yang Berhubungan dengan Kejadian Preeklampsi Berat di RSUD Kota Bekasi. Jurnal Ilmiah Kebidanan Stikes Medika Cikarang Vol 9 no 2.

Kementerian Kesehatan Republik Indonesia. 2014. Profil kesehatan Indonesia 2013. Jakarta : Kementerian Kesehatan Republik Indonesia

Kurniasari Devi. 2015. Hubungan Usia, Paritas dan Diabetes Melitus Pada Kehamilan dengan Kejadian Preeklampsi di Wilayah Kerja Puskesmas Rumbia Kabupaten Lampung .Jurnal Kesehatan Holistik Vol 9 no 3 .

Manuaba. 2008. Ilmu Kebidanan, Penyakit Kandungan dan KB. Jakarta : Buku Kedokteran. EGC

Marni, Suryaningaih, dkk. 2011. Asuhan Kebidanan Patologi. Yogykarta : Pustaka Pelajar ada hubungan yang bermakna antara usia ibu, paritas, usia kehamilan dan pendidikan dengan kejadian Preeklampsi Berat (PEB) dan faktor yang paling dominan dengan kejadian Preeklampsi Berat (PEB) di ruang kebidanan RSUD M.Yunus Bengkulu tahun 2016 dari penelitian ini adalah pendidikan lebih berhubungan dengan kejadian Preeklampsi Berat (PEB) dengan odd ratio (OR) 2,234.

Notoatmodjo. 2010. Metodologi Penelitian Kesehatan. Jakarta : PT. Rineka Cipta

Novaliasari Eka. 2014. Hubungan Usia dan Pendidikan dengan Kejadian Preeklampsi di RSUD Dr. Abdoer Rahem Situbondo.

Nugroho. 2010. Buku Ajar Obstetri. Yogyakarta : Nuha Medika

Patricia, 2016.Karakteristik Preeklampsi di RSUP Kandow Manado. Jurnal e-Clinic Vol 4 no 1.

Prawirohardjo. S. 2009. Pelayanan Kesehatan Maternal dan Neonatal. Jakarta : Yayasan Bina Pustaka

Ria Maryati. 2013. Hubungan Usia dan Pendidikan dengan Kejadian Preeklampsia Berat di Rumah Sakit Pusri Palembang.Jurnal Harapan Bangsa vol 1 no 1.

Sitti Nur Afridasari, dkk. 2012. Analisis Faktor Risiko Kejadian Preeklampsia di Rumah Sakit Umum Bahteramas.

Sri Rahayu Restu.2015. Faktor-faktor Yang Mempengaruhi Terjadinya Preeklampsi di RSUD Surakarta.Jurnal Gaussian Vol 4 no 2.

Tigor.H.Situmorang, dkk. 2016. Faktor-Faktor Yang Berhubungan Dengan Kejadian Preeklampsia Pada Ibu Hamil Di Poli KIA RSU Anutapura Palu.Jurnal Kesehatan Tadulako vol 2 no 1.

Varney, H, dkk. 2006. Buku Ajar Asuhan Kebidanan. Jakarta : EGC

Wijayarini, MA, dkk. 2001. Safe Motherhood, Modul Eklampsia-Materi Pendidikan Bidan. Jakarta : EGC

Wikjosastro, H. 2012. Ilmu Kebidanan. Jakarta : Yayasan Bina Pustaka Sarwono Prawirohardjo.

Yasril dan Heru Subaris. 2009. Analisis Multivariat Untuk Penelitian Kesehatan. Yogyakarta : Mitra Cendikia Offset

Yusrawati.2015. Hubungan Faktor Risiko dengan Kejadian Preeklampsi Berat di RSUP Padang.Jurnal Kesehatan Andalas Vol 4 no 2. 